Journal of Biotechnology and Strategic Health Research

\author{
Research Article / Araştırma Makalesi
}

http://dergipark.org.tr/tr/pub/bshr

\title{
Yoğun Bakım Hastalarında Gelişen Sağlık Hizmeti İle İlişkili Acinetobacter Baumanii Bakteriyemilerinin Retrospektif Değerlendirilmesi
}

\author{
Retrospective Evaluation of Healthcare-Associated Acinetobacter Baumanii \\ Bacteremia in Intensive Care Patients
}

(iD) Emel Yıldız', (iD Murat Emre Tokur ${ }^{1}$, (D) Canan Balc1 ${ }^{1}$, (DD Özlem Arık², (D) Sevil Alkan Çeviker ${ }^{3}$

${ }^{1}$ Kütahya Sağlık Bilimleri Üniversitesi, Tip Fakültesi, Anestezi ve Reanimasyon AD,

${ }^{2}$ Kütahya Sağlık Bilimleri Üniversitesi, Biyoistatistik

${ }^{3}$ Çanakkale Onsekiz Mart Üniversitesi, Tip Fakültesi, Enfeksiyon Hastalıkları ve Klinik Mikrobiyoloji Anabilim Dalı

ORCID ID: Emel Yildız, https://orcid.org/0000 00034493 2099, Murat Emre Tokur, https://orcid.org/0000 000239574971

Özlem Arık, https://orcid.org/0000 00029427 3733, Sevil Alkan Çeviker, https://orcid.org/0000-0003-1944-2477

*Sorumlu Yazar / Corresponding Author: Dr. Öğr. Üyesi Sevil Alkan Çeviker, e-posta / e-mail: s-ewil@hotmail.com

Geliş Tarihi / Received: 21-10-2020 Kabul Tarihi / Accepted: 14-12-2020 Yayın Tarihi / Online Published: 31-12-2020

Atıf Gösterimi/How to Cite: Yıldız E., Tokur M.E., Arık Ö., Alkan Çeviker S. Yoğun Bakım Hastalarında Gelişen Sağlık Hizmeti İle İlişkili

Acinetobacter Baumanii Bakteriyemilerinin Retrospektif Değerlendirilmesi, J Biotechnol and Strategic Health Res. 2020;4(3):283-291

\begin{tabular}{|c|c|}
\hline \multicolumn{2}{|l|}{ Özet } \\
\hline Amaç & $\begin{array}{l}\text { Çalışmada yoğun bakım ünitesinde (YBÜ) yatan hastalarda gelişen sağlık hizmeti ile ilişkili (SHI) Acinetobacter baumanii bakteriyemilerinin klinik özelliklerinin } \\
\text { irdelenmesi ve bu enfeksiyon gelișen hastalarda sağkalımı etkileyen risk faktörlerinin saptanması amaçlandı. }\end{array}$ \\
\hline Yöntem & $\begin{array}{l}\text { Yoğun bakım ünitelerinde yatan ve A. baumannii’ye bağlı SHİ bakteriyemi tanısı konulan, erişkin hastalar çalışmaya dahil edildi. En az bir set kan kültürlerinde A. } \\
\text { baumannii üremesi saptanan ve ilgili hekim/enfeksiyon hekimi tarafından SHİ bakteriyemi tanısı konulan hastalara ait verilere retrospektif olarak hasta dosyaları ve } \\
\text { hastane otomasyon sisteminden ulaşıldı. Yaş, cinsiyet, antibiyotik kullanım öyküleri, yatış tanısı, altta yatan hastalıklar, uygulanan invazif girişimler gibi risk faktörleri, } \\
\text { Basitleștirilmiş Akut Fizyoloji Skoru (Simplified Acute Physiology Score) SAPS II değerleri ve hastaların mortalite durumları değerlendirildi. }\end{array}$ \\
\hline Bulgular & 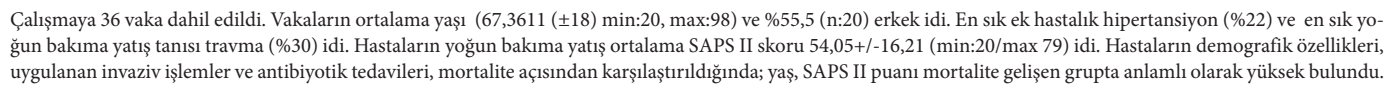 \\
\hline Sonuç & $\begin{array}{l}\text { Hastanede uzun süreli kalış, steroid ve antibiyotik maruziyeti varlığı, sınırlı terapötik seçenekleri olan A. baumannii bakteriyemili hastalarda artmış mortalite riskine } \\
\text { neden olabilir. Gereksiz antibiyotik tedavisinden kaçınmak ve sıkı enfeksiyon kontrol önlemleri gibi kontrol edilebilir risk faktörlerinin ortadan kaldırılması, A. bau- } \\
\text { mannii kaynaklı bakteriyemileri ve buna bağlı ölümleri azaltabilir. }\end{array}$ \\
\hline $\begin{array}{r}\text { Anahtar } \\
\text { kelimeler }\end{array}$ & Yoğun bakım, Acinetobacter baumannii, sağlık hizmeti ile ilişkili bakteriyemi. \\
\hline \multicolumn{2}{|l|}{ Abstract } \\
\hline Aim & $\begin{array}{l}\text { In this study, it was aimed to examine the clinical features of Acinetobacter baumannii bacteremias associated with health care (SHI) developing in patients in the intensive care unit and } \\
\text { to determine the risk factors affecting survival in patients with this infection. }\end{array}$ \\
\hline Methods & $\begin{array}{l}\text { Adult patients hospitalized in intensive care units (ICU) and diagnosed with SHI bacteremia due to A. baumannii were included in the study. The data of patients with A. baumannii } \\
\text { growth in at least one set of blood cultures and diagnosed with SHI bacteremia by the relevant physician / infectious physician were retrieved retrospectively from the patient files and } \\
\text { the hospital automation system. Risk factors such as age, gender, history of antibiotic use, hospitalization diagnosis, underlying diseases, invasive procedures applied, Simplified Acute } \\
\text { Physiology Score (SAPS) II values and mortality status of the patients were evaluated. }\end{array}$ \\
\hline Results & $\begin{array}{l}36 \text { cases were included in the study. The mean age of the cases was }(67.3611 \text { ( } \pm 18) \text { min: } 20, \text { max: } 98) \text { and } 55.5 \%(n: 20) \text { male. The most common comorbidities were hypertension }(22 \%) \\
\text { and the most common diagnosis of intensive care admission was trauma }(30 \%) \text {. The mean SAPS II score of the patients who were hospitalized in intensive care was } 54.05+/-16.21 \text { (min: } \\
20 \text { / max } 79) \text {. When demographic characteristics of patients, invasive procedures and antibiotic treatments were compared in terms of mortality; age, SAPS II score were found to be } \\
\text { significantly higher in the mortality group. }\end{array}$ \\
\hline Conlusion & $\begin{array}{l}\text { Prolonged hospital stay, presence of steroid and antibiotic exposure may lead to an increased risk of mortality in A. baumannii bacteremia patients with limited therapeutic options. Avoi- } \\
\text { ding unnecessary antibiotic therapy and eliminating controllable risk factors, such as strict infection control measures, can reduce bacteremia and related deaths caused by A. baumannii. }\end{array}$ \\
\hline Key words & Intensive care, Acinetobacter baumannii, healthcare associated bacteremia. \\
\hline
\end{tabular}




\section{GIIRIŞ}

Acinetobacter cinsi bakteriler, zorunlu aerop, gram negatif kokobasil, oksidaz negatif, hareketsiz, genellikle nitrat-negatif ve non-fermentatif basillerden oluşmaktadır. Acinetobacter türleri, doğada ve hastane ortamında yaygın olarak bulunmaktadırlar. Nemli ve kuru ortamda yaşayabilmekte, gıdalarda, sağlıklı insan cildinde ve sağlık çalışanlarının ellerinde uzun süre canlılığını devam ettirebilmektedirler ${ }^{1}$.

Acinetobacter türleri genel olarak virülansı düşük patojenlerdir, sağlıklı bireylerde enfeksiyon oluşturmaları oldukça güçtür. Özellikle, yaşlı ve immünitesi düşük bireylerde sağlık bakımı ilişkili enfeksiyonlara neden olmaktadırlar. Malignite, yanık, konağın savunma sistemini baskılayan durumlar ve konağın yaşı enfeksiyon gelişimini kolaylaştıran faktörlerdir. Son yillarda Acinetobacter türleri antibiyotiklere direnç kazanmaları ve salgınlara yol açabilmeleri nedenleriyle, başta yoğun bakım ünitelerinde olmak üzere, hastane enfeksiyonlarına neden olan başlica etkenlerden birisi haline gelmişlerdir ${ }^{2}$.

Acinetobacter türleri arasında en sık enfeksiyon etkeni olarak saptanan Acinetobacter baumannii olup, neden olduğu enfeksiyonlar arasında, ventilatör ilişkili pnömoni, bakteriyemi, idrar yolu enfeksiyonları, menenjit ve yara enfeksiyonları sayılabilir. A. baumannii, klinik seyri geçici bir bakteriyemiden septik şoka kadar değişebilen klinik seyirde enfeksiyonlara neden olabilir ${ }^{3}$.

Acinetobacter bakteriyemisi ile ilişkili kaba mortalite oranları \%6,5 ile \%57 arasında olarak bildirilmektedir ${ }^{4}$. A.baumannii bakteriyemileri; global düzeyde hastane enfeksiyonlarında sık karşılaşılan etkenlerden olması ve yüksek mortalite hızı nedenleri ile önemini korumaktadır.

Çalışmada yoğun bakım ünitesinde (YBÜ) yatan hastalarda gelişen sağlık hizmeti ile ilişkili (SHİ) A. baumannii bakteriyemilerinin klinik özelliklerinin irdelenmesi ve bu enfeksiyon gelişen hastalarda sağkalımı etkileyen risk faktörlerinin saptanması amaçlandı.

\section{YÖNTEM}

Ocak 2014-Ocak 2019 tarihleri arasında yoğun bakım ünitelerinde yatan ve A. baumanniìye bağlı SHİ bakteriyemi tanısı konulan, erişkin hastalar ( $\geq 18$ yaş) çalışmaya dahil edildi. YBÜ'nde yatan hastalara ait kan kültürleri incelendi. Kan kültürlerinde A. baumannii üremesi saptanan ve ilgili hekim/enfeksiyon hekimi tarafından SHİ bakteriyemi tanısı konulan hastalara ait verilere retrospektif olarak hasta dosyaları ve hastane otomasyon sisteminden ulaşıldı. Demografik olarak yaş, cinsiyet, antibiyotik kullanım öyküleri, hastaneye yatış tanısı, altta yatan hastalıklar (diyabetes mellitus (DM), immunsüpresyon, malignite, travma, kronik böbrek yetmezliği, serebrovasküler hastalık (SVH) vs..), transfüzyon, uygulanan invazif girişimler (foley sonda, santral venöz kateter, transfüzyon, mekanik ventilasyon vs..) gibi risk faktörleri, Basitleştirilmiş Akut Fizyoloji Skoru (Simplified Acute Physiology Score (SAPS) II değerleri ile C-Reaktif Protein (CRP) ve hastaların mortalite durumları değerlendirildi. Kan kültürlerinin sonuçları değerlendirilerek, Centers for Disease Control and Prevention (CDC) kriterlerine göre SHİ bakteriyemi tanısı konulan vakalar çalışmaya dahil edildi. SHİ A. baumannii bakteriyemisi, kan kültürü sadece $A$. baumannii için pozitif olan ve hastaneye yatıştan en az 48 saat sonra klinik bulgu veya enfeksiyon semptomları olan hastalar olarak tanımlandı. Çalışmamızda, SHİ A. baumannii bakteriyemisi, bu mikroorganizmanın en az bir kan kültüründen izolasyonu olarak tanımlandı. Vasküler kateterle ilişkili bakteriyemi ise; santral venöz kateteri olan ve başka bir enfeksiyon kaynağı olmayan hastada gelişen, pozitif periferik kan kültürünün olması olarak tanımlandı. Her bir hasta için sadece bir bakteriyemi epizodu çalışmaya dahil edildi.

\section{İstatistiksel analiz}

Tüm istatistiksel değerlendirmeler için IBM SPSS Statistics for Windows Version 20.0 (Statistical Package for the Social Sciences, IBM Corp., Armonk, NY, ABD) paket programı kullanıldı. Değişkenler ortalama ve yüzde olarak ifade edildi. İstatistiksel olarak \%95 güven aralığında ve $\mathrm{p}<0.05$ 
olan değerler anlamlı kabul edildi. Tanımlayıcı İstatistikler, çapraz tablolar, frekans tabloları, Mann-Whitney U Testi, Ki-kare Testleri, Olağanlık İlişki Katsayısı, Eta İlişki Katsayısı, Phi İlişki Katsayısı kullanılarak değerlendirildi.

\section{Etik Kurul}

Çalışmanın yapılabilmesi için Kütahya İl Sağlık Müdürlüğü ve Kütahya Sağlık Bilimleri Üniversitesi Rektörlüğü Girişimsel Olmayan Klinik Araştırmalar Etik Kurulu'na başvuruldu ve 01.10.2019 tarihli ve /2019/10 karara istinaden onay alındı.

\section{BULGULAR}

Dahil edilme kriterlerini karşılayan ve verilerine ulaşılabilen SHİ A. baumannii bakteriyemisi olan 36 vaka çalışmaya dahil edildi. 2014 yılında 11, 2015 yilında 4, 2016 yılında 6, 2017 yılında 6, 2018 yilında 7, 2019 yilında 2 (ilk ay) vaka saptandı. Çalışma popülasyonunun ortalama yaşı $(67,3611( \pm 18)$ min:20, max:98) idi. Bunların \%55,5 (n:20) erkek, \% 44,4 (n:16) kadın cinsiyette idi. Hastaların 35 (\%97)'inde yoğun bakım yatışları sırasında ek hastalık vardı. En sık altta yatan hastalık hipertansiyon (HT) (\%22) olup, en sık hastaların en sık yoğun bakıma yatış tanısı travma ( \%30) idi (Tablo 1).

Hastaların 19 (\%52)'unda bakteriyemi saptanmadan önce eritrosit, trombosit veya taze donmuş plazma ürünlerinden en az bir kez uygulandığı saptandı (Tablo 1).

Hastaların yoğun bakıma yatış SAPS II skoru ortalama 54,05+/-16,21 (min:20/max 79) olarak tespit edildi. Hastaların bakteriyemi tespit edildiği sırada bakılan CPR değerleri ortalama 188,38+/-99,45 (min:23,max:458) olarak tespit edildi.

Acinetobacter bakteriyemisi gelişen hastaların 19 (\%52 )'u exitus olurken, 17 (\%48)'si yoğun bakımdan çıkartılmıştır. Cinsiyet ile sağ kalım arasında yaklaşık olarak \%30 'luk bir ilişki saptandı. İstatistiksel açıdan \%5 hata payı ile anlamsı iken; \%10 hata payı ile anlamlı olarak saptandı (Tablo
1).

Mortalite gelişen ile mortalite gelişmeyen gruplar arasında ortalama YBÜ’ de kalış süresi açısından istatistiksel açıdan anlamlı fark olmadığ ${ }_{1} \operatorname{saptand}_{1}$ ( $\mathrm{p}>0.05, \mathrm{p}>0.05$ ) (Tablo 1).

Tablo 1. Demografik özellikler, CRP, SAPS II skorlama puanı, mortalite durumları

\begin{tabular}{|c|c|c|}
\hline & $\mathbf{n}$ & $\%$ \\
\hline Yaş ${ }^{*}$ & \multicolumn{2}{|c|}{$67,36 \pm 18.37$} \\
\hline \multicolumn{3}{|l|}{ Cinsiyet (\%) } \\
\hline Kadın & 16 & 44.4 \\
\hline Erkek & 20 & 55.6 \\
\hline \multicolumn{3}{|l|}{ Ek hastalıklar** } \\
\hline Diabetes mellitus & 6 & 16 \\
\hline Kronik böbrek yetmezliği (KBY) & 2 & 5 \\
\hline Kronik obstrüktif akciğer hastalığı & 6 & 16 \\
\hline Hipertansiyon & 8 & 22 \\
\hline Malignite & 1 & 2 \\
\hline Konjestif kalp yetmezliği & 3 & 8 \\
\hline Serebrovasküler hastalık & 3 & 8 \\
\hline Hipotiroidi & 2 & 5 \\
\hline Koroner arter hastalığı & 4 & 11 \\
\hline Parkinson & 2 & 5 \\
\hline Alzehimer & 2 & 5 \\
\hline Karaciğer yetmezliği & 1 & 2 \\
\hline \multicolumn{3}{|l|}{ Yatış tanıları ${ }^{\star *}$} \\
\hline Kardiyopulmoner arrest & 7 & 19 \\
\hline Travma & 11 & 30 \\
\hline Sepsis & 5 & 13 \\
\hline Akut Solunum yetmezliği & 7 & 19 \\
\hline Serebrovasküler hastalık & 4 & 11 \\
\hline Konjestif kalp yetmezliği & 2 & 5 \\
\hline Transfüzyon durumu ${ }^{* *}$ & 19 & 52 \\
\hline Yatış SAPS II skoru* & \multicolumn{2}{|c|}{$54,05 \pm 16,21$} \\
\hline $\mathrm{CRP}^{\star}$ & \multicolumn{2}{|c|}{$188,38 \pm 99,45$} \\
\hline Yoğun bakım yatıș gün sayısı* & \multicolumn{2}{|c|}{$66,52 \pm 49,35$} \\
\hline Mortalite $^{\star \star}$ & 19 & 52,77 \\
\hline
\end{tabular}

Tüm hastaların invaziv mekanik ventilatör desteği, santral venöz kateteri ve idrar sondası vardı. Hastaların 21 
J Biotechnol and Strategic Health Res. 2020;4(3):283-291

YILDIZ, TOKUR, BALCI, ARIK, ÇEVIKKER: Acinetobacter baumanii bakteriyemilerinin retrospektif değerlendirilmesi

(\%58)'inin nazogastrik sondası, 4 (\%11)'ünün invaziv intraarteryel kateterizasyonu vardi (Tablo 2).

\begin{tabular}{|l|c|c|}
\hline Tablo 2. Uygulanan invaziv işlemler \\
\hline & n & $\%$ \\
\hline İnvaziv mekanik ventilasyon & 36 & 100 \\
\hline Üriner kateterizasyon & 36 & 100 \\
\hline Nazogastrik sonda & 21 & 58 \\
\hline Santral venöz kateterizasyon & 36 & 100 \\
\hline İnvaziv arteriyel kateterizasyon & 4 & 11 \\
\hline${ }^{\star}$ Veriler n(\%) olarak verilmiştir. & \multicolumn{2}{|l}{} \\
\hline
\end{tabular}

Acinetobacter bakteriyemisi gelişimi öncesi kullanılan antimikrobiyal ajanlara bakıldığında en sık meropenem olduğu saptandi ( Tablo 3).

\begin{tabular}{|l|c|c|}
\hline \multicolumn{3}{|l|}{ Tablo 3. Kullanılan antimikrobiyal ajanlar } \\
\hline Moksifloksasin & $\mathbf{n}$ & $\%$ \\
\hline Levofloksasin & 5 & 13 \\
\hline Siprofloksasin & 1 & 2 \\
\hline Meropenem & 0 & 0 \\
\hline İmipenem & 16 & 44 \\
\hline Sefuroksim & 1 & 2 \\
\hline Seftazidim & 1 & 2 \\
\hline Flukonazol & 2 & 5 \\
\hline Kaspofungin & 3 & 8 \\
\hline Piperasilin tazobaktam & 1 & 2 \\
\hline Klindamisin & 8 & 22 \\
\hline Ertapenem & 1 & 2 \\
\hline Tigesiklin & 1 & 2 \\
\hline Linezolid & 3 & 8 \\
\hline Teikoplanin & 3 & 8 \\
\hline Vankomisin & 5 & 13 \\
\hline Kolistin & 2 & 5 \\
\hline Gentamisin & 1 & 2 \\
\hline$*$ Veriler n(\%) olarak verilmiştir. & & 2 \\
\hline
\end{tabular}

Hastaların demografik özellikleri, uygulanan invaziv işlemler ve almakta olduğu antibiyoterapiler mortalite açısından karşılaştırıldı ve Tablo 4'de sunulduğu gibi yaş, hastanede kalış süresi, SAPS II skorlama puanı mortalite gelişen grupta gelişmeyen gruba göre anlamlı olarak yüksek bulundu.

Mortalite gelişen ile mortalite gelişmeyen gruplar arasında yaş ortalama açısından istatistiksel açıdan anlamlı fark olduğu saptandı $(\mathrm{p}<0.05)$. Sağkalım ile yaş arasında \%90 `lık yüksek bir ilişki olduğu ve exitus grubunda yer alan hastaların yaş ortalamasının daha yüksek olduğu saptandı ( Tablo 4).

Mortalite gelişen ile mortalite gelişmeyen gruplar arasında ortalama hastanede kalıs süreleri, SAP II skoru, SAPS II yüzde değeri açısından istatistiksel açıdan anlamlı fark olduğu ve $(\mathrm{p}<0.045, \mathrm{p}<0.05, \mathrm{p}<0.05)$ mortalite gelişmeyenlerin ortalama hastanede kalış sürelerinin daha uzun olduğu saptandı ( Tablo 4).

\begin{tabular}{|c|c|c|c|}
\hline & $\begin{array}{c}\text { Mortalite gelişen } \\
\quad(\mathbf{n}=19) \\
(\text { ortanca } \\
\text { değer+/- SD) }\end{array}$ & $\begin{array}{c}\text { Mortalite } \\
\text { gelişmey- } \\
\text { en }(\mathbf{n}=17) \\
\text { (ortanca } \\
\text { değer+/- SD) }\end{array}$ & $\underset{\text { değeri }}{\mathbf{p}}$ \\
\hline Yaş & $71.73 \pm 17.27$ & $62.47 \pm 18.83$ & $0,047^{*}$ \\
\hline $\begin{array}{l}\text { Hastanede } \\
\text { kalış süresi } \\
\text { (gün) }\end{array}$ & $37,26 \pm 16,41$ & $99,23 \pm 53,58$ & $<0,001$ \\
\hline SAPS II skoru & $66,10 \pm 6,41$ & $40,58 \pm 12,79$ & $<0,001$ \\
\hline SAPS II yüzde & $0,75 \pm 0,09$ & $0,31 \pm 0,21$ & $<0,001$ \\
\hline
\end{tabular}

\section{TARTIŞMA}

Acinetobacter baumannii dünya genelinde ve ülkemizde birçok merkezde önemli bir nozokomiyal patojen haline gelmiştir. Acinetobacter bakteriyemilerinin görülme sıklığının artmasının yanısıra, bu patojenin pnömoni, menenjit, bakteriyemi gibi ağır infeksiyonlara neden olması, antibiyotiklere karşı çoğul direnç gösterip tedavide güçlüklere yol açması sonucu artmış mortalite oranları nedeniyle önemi artmaktadır ${ }^{5-8}$. 
İleri yaş, yaygın antibiyotik kullanımı, santral venöz kateterizasyon ve nazogastrik tüpün varlığı, genellikle tüm YBÜ hastalarında yaygın görülen A. baumannii de dahil olmak üzere nozokomiyal enfeksiyonların gelişmesi için risk faktörleridir ${ }^{5-8}$. Literatürde Acinetobacter spp. enfeksiyonlarında bazı çalışmalarda 50 yaş bazı çalışmalarda 65 yaş üzerinde olmanın mortaliteyi arttırdığ gösterilmiş$\operatorname{tir}^{7-9}$.

Yang ve ark. ${ }^{10}$ yaptıkları bir çalışmada hastane kökenli A. baumannii bakteriyemisi olan toplam 118 hastayı değerlendirmişler ve hastalığın şiddetini, MODS (multiple organ dysfunction syndrome) varlığı ve yüksek APACHE II (Acute Physiology and Chronic Health Evaluation II) skoru, mekanik ventilasyon kullanımı ile ilişkili olarak bulmuşlardır. Özellikle mekanik ventilasyonun mortalitede rolü vurgulanmış bu da solunum fonksiyon bozukluğunun kötü sonuca neden olabileceğini düşündürmüştür. Bizim hasta grubumuzun da hepsinin mekanik ventilasyon kullanımı mevcuttu ancak kontrol grubumuz olmadığı için değerlendirme yapılamadı.

Blot ve ark. ${ }^{11}$ tarafından 2003 yılında yapılan çalışmada SHİ A. baumannii bakteriyemisinin yoğun bakımdaki hastalarda mortalite oranını artırıp artırmadığını araştııılmış ve prognozun altta yatan hastalığın şiddeti ve akut hastalığın şiddeti ile ilişkili olduğu belirtilmiştir. YBÜ hastalarında A. baumannii bakteriyemisinin yüksek mortalite (\% 42.2) ile ilişkili olduğunu göstermiştir.

Chusri ve ark. ${ }^{12}$ yaptıkları bir çalışmada toplum ve hastane kaynaklı A. baumannii bakteriyemilerinin çoklu ilaç direnci nedeniyle en sorunlu patojenlerden biri olarak bildirmiştir. Leão ve ark. ${ }^{13}$ yaptığı bir çalışmada hematolojik maligniteleri olan hastalarda A. baumannii bakteriyemisine bağlı mortalite oranını $\% 63,5$ olarak bildirmiştir. Literatürde de benzer şekilde, $\% 30$ ile $\% 80$ aralığında mortalite oranı olduğu ve bu oranın hastanın komorbiditesine göre değiştiği bildirilmiştir ${ }^{14}$. Güneş ve ark. ${ }^{15}$ tarafından yapılan bir çalışmada gram negatif bakteriyemili hastalarda malignensi, konjestif kalp yetmezliği ve diabetes mellitus (DM) varlığı mortalite ile ilişkili anlamlı risk faktörü olarak bulunmuştur. Yine aynı çalışmada YBÜ’sinde $A$. baumannii mortalitesi \%47,1 bulunmuştur. Kwon ve ark. ${ }^{16}$ çalışmasında çok ilaca dirençli A. baumannii bakteriyemisi olan hastalarda sağkalımı etkileyen faktörler değerlendirilmiş ve $A$. baumannii hastane salgınlarının görülme sıklığı artmakta olduğunu ve buna bağlı ölüm oranı \% 22 ile \% 59 arasında değiştiğini belirtmişlerdir. Bizim çalışmamızda mortalite \%52,77 bulundu.

Amerika'da YBÜ enfeksiyonlarında en sik saptanan etkenler sırasıyla; P.aeruginosa, Enterobacter ve Klebsiella türleri olarak bulunmuş ${ }^{17}$. Brezilya'da ise Acinetobacter türleri en sık saptanan etken olarak bulunmuştur ${ }^{18}$. Güneş ve ark. ${ }^{15}$ da A.baumannii, P. aeruginosa ve K.pneumoniae'y 1 en sık etken olarak bildirmiştir.

Son yıllarda dünyanın farklı bölgelerinde A. baumannii bakteriyemisinde mortalite için risk faktörleri bildirilmiştir. Yaşlllık, nötropeni, malignite, bakteriyemi öncesi, cerrahi, transplantasyon sonrası olmak, Pitt bakteriyemi skoru veya Akut Fizyoloji ve Kronik Sağlık Değerlendirmesi II skoru ile tanımlanan hastalığın şiddeti, yoğun bakımda kalış, düşük albümin düzeyi, solunum yolu enfeksiyonuna sekonder bakteriyemi varlığı ve uygunsuz antimikrobiyal tedavi sayılmaktadır ${ }^{19}$. Altta yatan hematolojik hastalığı olan hastalarda A. baumannii enfeksiyonları için bilinen risk faktörlerinden birinin geniş spektrumlu antibiyotiklerin uzun süreli kullanımı olduğu bildirilmektedir ${ }^{20}$. Bizim çalışmamızda ise bakteriyemi öncesinde meropenem en sık kullanılan antibiyotik olarak saptandı.

Yoğun bakım ünitelerinde enfeksiyon kontrol programını iyileştirmek için çeşitli girişimlerde bulunulmuştur. Tüm YBÜ enfeksiyon kontrol hemşiresi tarafından günlük olarak ziyaret edilmesi, YBÜ’ne enfeksiyon kontrol önlemleri hakkında hatırlatıcı posterlein asılması ve Gram-negatif/ Gram-pozitif bakterilerle enfekte olan hastaların yatak 
kenarlarına hatırlatıcı kartlar yerleştirilmesi, alkol bazlı el dezenfektanlarının hasta yatak kenarlarına konarak tüm sağlık personeli için rutin bir enfeksiyon kontrol eğitim programı yapılması ve YBÜ' de yeterli sayıda personel olmasına dikkat edilmesi önerilmektedir ${ }^{21}$. Bizim çalı̧smamizda 2014 yilında 11, 2015 yilında 4, 2016 yilında 6, 2017 yllında 6, 2018 yllinda 7, 2019 yllinda 2 (ilk ay) vakaya rastlanmıştır. Çalışmamızda, önceki yıllara göre; yllar içerisinde Acinetobacter bakteriyemisi gelişen hasta sayılarında azalma olduğu saptandı. Bunun nedeni olarak etkili enfeksiyon kontrol programları, sağlık personelinin eğitilmesi ve antibiyotik kullanımının enfeksiyon hekimlerinin kontrolünde olmasının rol oynadığı düşünülmektedir. Ancak T.C. Sağlık Bakanlığı Ulusal Sağlık Hizmeti İlişkili Enfeksiyonlar Sürveyans Ağg Özet Raporları̉na bakıldığında etkene özgü bakteriyemi etkenlerine ait veriye ulaşılamadığı için diğer hastanelerin verileri ile kıyaslama yapılamadi.

2010-2015 yılları arasında Beyrut'taki üçüncü basamak bir hastanede yapılan bir çalı̧̧mada A. baumannii bakteriyemisi tespit edilmiş olan 85 hastanın risk faktörleri ve klinik sonuçları incelenmiş yüksek doz steroid maruziyeti, DM varlığı, mekanik ventilasyon ihtiyaç durumu, kolistin ve tigesiklin kullanımı, septik şokun varlığına ve yoğun bakım ünitesinde kalmanın kötü prognozla ilişkili olduğunu göstermiştir.Kaba ölüm oranı\% 63,5 olarak bildirilmiştir ${ }^{22}$. Guo ve ark. ${ }^{23}$ da A. baumannii bakteriyemili hastalarda immünosupresyonun daha kötü prognozla ilişkili olduğunu bildirmiştir.

Başka bir çalışmada, hastanede uzun süreli kalış, steroid ve antibiyotik maruziyetinin A.baumannii bakteriyemisine bağlı mortaliteyi etkilediğini belirtmişlerdir. A. baumannii enfeksiyonunu tedavi etmektense, bakteriyemi gelişmemesi için önlem alınmasının önemi vurgulanmıştır³.

Acinetobacter türlerinin hastane ortamında uzun süre canlılığını koruması, hasta-personel, çevre ve kullanılan aletlerde kolonize olmaları, nozokomiyal infeksiyonlara yol açmalarına neden olmaktadır. Yoğun bakım ünitelerindeki nozokomiyal yayılım ventilatör ekipmanları, eldivenler, kolonize personel, kontamine total parenteral beslenme ve bilgisayar klavyeleri ile olur. YBÜ’lerde izlenen kritik hastalar daha sık ve daha uzun süre invaziv islemlere ihtiyaç duyduğundan ve sıklıkla antimikrobiyal tedavi almakta olduğundan, A.baumannii bakteriyemisi epizotları bu grup hastalarda daha sık görülmektedir. Yetişkinlerde 10 ylllık dönem içinde görülen Acinetobacter bakteriyemisi ile ilgili bir çalışmada, bakteriyemi gelişimi için istatistiksel olarak anlamlı risk faktörleri 65 yaş üzerinde olmak, septik şok gelişimi ve koagülopati olarak bildirilmiştir. Bu çalışmada en sık kaynak alt solunum yolu olup, enfeksiyonların \%46’sından sorumlu olduğu düşünülmüş, hastaların yarısında septik şok, respiratuvar distres sendromu veya multiorgan yetmezliği gelişmiştir. Kaba mortalite hızı \%54 gibi yüksek oranda bulunmuştur ${ }^{4}$.

Baran ve ark. ${ }^{4}$; Acinetobacter bakteriyemilerinde, ilk 14 günde ölen hastalardaki mortalite risk faktörü incelemelerinde; tek değişkenli analizinde; 65 yaşın üzerinde olma, APACHE II skoru yüksekliği, ampirik antibiyotik tedavisinin uygun olmaması, bilincin kapalı olması, hipotansiyon varlı̆̆ı, lökopeninin olması, septik şok varlığı, üre yüksekliği, mekanik ventilasyon desteği, total parenteral nütrisyon desteği, arteriyel kateterizasyon, izole edilen suşun siprofloksasin ve imipeneme dirençli olması risk faktörü olarak saptanmıştır. Ballouz ve ark. ${ }^{24}$ ise, tek değişkenli analizde, yüksek doz steroid, kolistin ve tigesiklin kullanımı, DM, mekanik ventilasyon, septik şok varlığına ve kritik bakım ünitesinde kalışa maruz kalmanın kötü prognozla ilişkili olduğunu göstermiştir. Çok değişkenli analizde yüksek doz steroid kullanımı ve septik şok varlığı anlamlı olarak saptanmıştır.

Acinetobacter baumannii bakteriyemisi olan hastalarda, mortalite, serviste yatan hastalarda $\% 5$ ve yoğun bakım ünitelerinde $\% 54$ oranlarına ulaşmaktadır. A. baumannii suşlarında karbapenemler dahil birçok antibiyotik grubuna gittikçe artan direnç nedeniyle başlanan ampirik tedavi 
çoğu zaman uygun olmamaktadır. Ulu-Kılıc ve ark. ${ }^{8}$ çalışmasında ise; hastalara uygulanan mekanik ventilasyon desteği, trakeostomi, santral venöz kateter, arteriyel kateter, üriner sonda,nazogastrik sonda ve ğöğüs tüpü yerleştirilmesi gibi invaziv girişimler mortalite için risk faktörü olarak anlamlı bulunmadı olarak bildirilmiştir.

Falagas ve ark. 25 altı farklı eşleştirmeli vaka-kontrol çalışmasının ele alındığı derlemesinde A. baumannii enfeksiyonlarının mortalitesinin hastanede servislerde yatan olgularda \%7,8-23, yoğun bakım ünitesinde yatanlarda ise \%10-\%43 arasında değiştiğini bildirmiştir. A. baumannii bakteriyemisinin, hastanede ve yoğun bakımda yatış süresinin uzamasına yol açmakta, tanı amaçlı girişimler ve tedavi maliyetine bağlı olarak ciddi bir ekonomik yük oluşturduğu bildirilmiştir.

Acinetobacter baumannii çok hızla direnç geliştirebilen bir bakteridir. İmipenem Acinetobacter türlerine en etkili antibiyotik olmasına rağmen dirençli suşların giderek arttı̆̆ı bilinmektedir. Çoğul antibiyotik direnci olan A. baumannii bakteriyemileri daha yüksek mortalite hızı, daha uzun sure hastanede kalış ve daha fazla hastane maliyeti olarak karşımıza çıkmaktadır. Enfeksiyon düşünülen hastalara hemen her zaman ampirik tedavi başlanmasına rağmen bunların çoğunluğu uygun tedavi değildir.

Karbapenem dirençli A. baumannii ile enfekte olan hastalarda mortalite tahminleri sistematik bir gözden geçirme, özellikle kritik hastalar arasında ventilatörle ilişkili pnömoni dahil olmak üzere nozokomiyal enfeksiyonlara, ağırlıklı olarak kan dolaşımı ve solunum enfeksiyonlarına neden olan önemli bir fırsatçı patojendir. Yoğun bakım ünitesinde veya hastaneye başvuruda APACHE II skorunun, sağkalım grupta mortalite gelişen gruba göre daha düşük seyretmiştir ${ }^{26}$.

Karbapenem dirençli A. baumannii, kolonizasyondan septik şoka kadar birçok klinik semptomlara yol açabi$\operatorname{lir}^{27}$. Joung ve ark. ${ }^{28}$ APACHE II skorunun Acinetobacter pnömonisinde prognoz tahmini için yararlı olduğunu göstermiştir. Inchai ve ark. ${ }^{29} A$. baumannii enfeksiyonlarında 30 günlük sürede mortalite gelişiminde; çok değişkenli analiz sonucunda, septik şok varlığında, SAPS II skorunun ve SOFA skorunun yüksek olması ve uygun olmayan antibiyotik tedavisi ile ilişkili anlamlı bağımsız faktörleri olduğunu bildirmişlerdir. Çalışmamız bakteriyemi sırasındaki septik şokun mortalite için bağımsız bir risk faktörü olduğunu göstermiştir. Ayrıca; çalışmamızda mortalite gelişen ile mortalite gelişmeyen gruplar arasında ortalama hastanede kalış süreleri, SAP II skoru, SAPS II yüzde değeri açısından istatistiksel açıdan anlamlı fark olduğu benzer şekilde saptand1.

Acinetobacter baumannii, antimikrobiyallere karşı direnç geliştirme, gelişmiş çevresel direnç ve eğilime sahip belirgin bir nozokomiyal patojen olarak ortaya çıkan, yüksek morbidite ve mortalite ile ilişkilidir ve uzun süreli hastanede kalış süresine ve yüksek hastane maliyetlerine sebep olmaktadır. Acinetobacter cinsi bakterilerin, özellikle kritik hastalığı olan hastalarda, klinik seyri iyi huylu bir geçici bakteriyemiden fulminan septik şoka kadar değişebilen kan akımı enfeksiyonlarına neden olma kabiliyeti özellikle önemlidir. Bununla birlikte, atfedilebilir mortalite ile altta yatan hastalıklara ve hastaların komorbid koşullarına atfedilebilir olanı ayırt etmek zordur ${ }^{23,30}$. Çalışmamızda da atfedilebilir mortalite \% 70,3 idi, bu da bakteriyeminin sonuç üzerinde önemli bir etkisi olduğunu göstermektedir.

Sağlık hizmeti verilen ortamlarda kolonize olduktan sonra eradikasyonu zor olan Acinetobacter türleri ile olan enfeksiyonlarla mücadelenin bir diğer sorunu da karbapenem direncidir. Karbapenem direnci Dünya Sağlık Örgütü Orta Asya ve Doğu Avrupa Antimikrobiyal Direnç Sürveyansı 2020 Ylllık Raporu (Central Asian and Eastern European Surveillance of Antimicrobial Resistance Annual Report (CAESAR) 2020) Acinetobacter spp. Avrupa Bölgesi içinde büyük ölçüde değişiklik gösterdiğini, bu oranın; Belçika, Danimarka, Finlandiya, Malta, Hollanda ve Norveç’te \%1'in altında iken, Güney ve Doğu Avrupadaki birçok 
J Biotechnol and Strategic Health Res. 2020;4(3):283-291

ülkede $>\% 50$ 'nin üzerinde olduğu bildirilmiştir. ${ }^{31}$ Bizim çalışmamızda da meropenem direnci \%44 ve imipenem direnci \%2olarak saptandı. Bu nedenle ülkemiz için de halen gündemini koruyan bir enfeksiyon etkeni olmaya devam etmektedir. Sonuç olarak, hastalarda mortaliteye işaret eden risk faktörlerinin bilinmesi ve bu hastaların yakın izlenerek bakteriyeminin erken belirlenmesi hastanın prognozu açısından önem taşımaktadır. Hastanede uzun süreli kalış ve antibiyotik maruziyeti varlığı, sınırlı terapötik seçenekleri olan A. baumannii bakteriyemili hastalarda artmış mortalite riskine neden olabilir. Gereksiz antibiyotik tedavisinden kaçınmak ve sıkı enfeksiyon kontrol önlemleri gibi kontrol edilebilir risk faktörlerinin ortadan kaldırılması, A. baumannii kaynaklı bakteriyemileri ve buna bağlı ölümleri azaltabilir.

\section{Çalışmanın kısıtlılıkları}

Çalışmamızın retrospektif ve tek kurumu kapsayan bir çalışma olması nedeniyle kısıtlılıkları mevcuttur.

\section{Hasta Onamı}

Bu çalışma, tıbbi kayıtlarının retrospektif değerlendirilmesi ile elde edildi. Hastane yatışı sırasında alınan bilgilendirilmiş onam formu dışında onam formu alınmadı.

\section{Çıkar Çatışması}

Yazarlar çıkar çatışması bildirmemişlerdir.

\section{Finansal Destek}

Yazarlar bu çalışma için finansal destek almadıklarını beyan etmişlerdir. 
J Biotechnol and Strategic Health Res. 2020;4(3):283-291

YILDIZ, TOKUR, BALCI, ARIK, ÇEVIKER: Acinetobacter baumanii bakteriyemilerinin retrospektif değerlendirilmesi

\section{Kaynaklar}

1. Protic D, Pejovic A, Andjelkovic D, et al. Nosocomial Infections Caused by Acinetobacter baumannii: Are We Losing the Battle? Surg Infect (Larchmt). 2016;17(2):236-242. doi:10.1089/sur.2015.128

2. Uçar M, Kutlu M, Kaleli İ. Acinetobacter Türlerine Bă̆lı Kan Dolaşımı İnfeksiyonlarında Risk Faktörleri: IIleriye Dönük Bir Olgu-Kontrol Çalışsması. Klimik Derg. 2015; 28: 103-107. doi: 10.5152/kd.2015.21

3. Ballouz T, Aridi J, Afif C, et al. Risk Factors, Clinical Presentation, and Outcome of Acinetobacter baumannii Bacteremia. Front Cell Infect Microbiol. 2017;7:156. doi: 10.3389/ fcimb.2017.00156

4. Baran G, Erbay A, Bodur $H$, et al. Risk factors for nosocomial imipenem-resistant Acinetobacter baumannii infections Int J Infect Dis. 2008;12(1):16-21. doi: 10.1016/j. ijid.2007.03.005

5. Dizbay M, Tunccan OG, Sezer BE, et al. Nosocomial imipenem-resistant Acinetobacter baumannii infections: epidemiology and risk factors. Scand J Infect Dis. 2010;42(10):741-746. doi:10.3109/00365548.2010.489568

6. Turkoglu M, Mirza E, Tunçcan ÖG, et al. Acinetobacter baumannii infection in patients with hematologic malignancies in intensive care unit: risk factors and impact on mortality. J Crit Care. 2011; 26(5):460-467. doi: 10.1016/j.jcrc.2011.04.007.

7. Ozdemir K, Turgut H, Dikmen A, ve ark. Yoğun bakım ünitesinde yatan yașlı hastalarda Acinetobacter baumannii enfeksiyonunun sonuçları. Pamukkale Tip Derg. 2015;2:100-104.

8. Ulu-Kllic A, Ergonul O, Kocagul-Celikbaș A, ve ark. Acinetobacter baumannii bakteriyemilerinde mortalite icin risk faktorleri. Klimik Derg. 2011;24(3):162-166.

9. Grupper M, Sprecher H, Mashiach T, Finkelstein R. Attributable mortality of nosocomial Acinetobacter bacteremia. Infect Control Hosp Epidemiol. 2007;28(3):293-298.

10. Yang S, Sun J, Wu X, et al. Determinants of Mortality in Patients with Nosocomial Acinetobacter baumannii Bacteremia in Southwest China: A Five-Year Case-Control Study. Can J Infect Dis Med Microbiol. 2018:3150965. doi: 10.1155/2018/3150965.

11. Blot S, Vandewoude K, Colardyn F. Nosocomial bacteremia involving Acinetobacter baumannii in critically ill patients: a matched cohort study. Intensive Care Med. 2003;29(3):471475. doi:10.1007/s00134-003-1648-8

12. Chusri S, Chongsuvivatwong V, Silpapojakul K, et al. Clinical characteristics and outcomes of community and hospital-acquired Acinetobacter baumannii bacteremia. J Microbiol Immunol Infect. 2019;52(5). 796-806. doi.org/10.1016/j.jmii.2019.03.004

13. Leao AC, Menezes PR, Oliveira MS, et al. Acinetobacter spp. are associated with a higher mortality in intensive care patients with bacteremia: a survival analysis. BMC Infect Dis. 2016;16:386. https://doi.org/ 10.1186/s12879-016-1695-8

14. Gu Z, Han Y, Meng T, Zhao S, et al. Risk Factors and Clinical Outcomes for Patients With Acinetobacter baumannii Bacteremia. Medicine (Baltimore). 2016 Mar;95(9):e2943. doi: 10.1097/MD.0000000000002943. PMID: 26945403; PMCID: PMC4782887.

15. Güneş F, Ak Ö, Hacıseyitoğlu D, ve ark. Gram Negatif Bakteriyemi Etkenleri ve Hastalarda Mortalite İlişkili Risk FaktörlerininDeğerlendirilmesi Gaziosmanpaşa Üniversitesi Tip Fakültesi Derg. 2016;8(3): 150-162.

16. Kwon KT, Oh WS, Song JH, et al. Impact of imipenem resistance on mortality in patients with Acinetobacter bacteraemia. J Antimicrob Chemother. 2007;59(3):525-530. doi:10.1093/jac/dkl499
17. Wisplinghoff H, Bischoff T, Tallent SM, et al. Nosocomial bloodstream infections in US hospitals: analysis of 24,179 cases from a prospective nationwide surveillance study. Clin Infect Dis. 2004;39(3):309-317. doi:10.1086/421946

18. Marra AR, Camargo LF, Pignatari AC, et al. Nosocomial bloodstream infections in Brazilian hospitals: analysis of 2,563 cases from a prospective nationwide surveillance study. J Clin Microbiol. 2011;49(5):1866-1871. doi:10.1128/JCM.00376-11

19. Zhou H, Yao Y, Zhu B, et al. Risk factors for acquisition and mortality of multidrug-resistant Acinetobacter baumannii bacteremia: A retrospective study from a Chinese hospital. Medicine (Baltimore). 2019;98:e14937. doi.org/10.1097/MD.0000000000014937

20. Shargian-Alon L, Gafter-Gvili A, Ben-Zvi H, et al. Risk factors for mortality due to Acinetobacter baumannii bacteremia in patients with hematological malignancies - a retrospective study. Leuk Lymphoma. 2019;60:2787-2792. doi:10.1080/10428194.2019.1599113

21. Metan G, Sariguzel F, Sumerkan B. Factors influencing survival in patients with multi-drug-resistant Acinetobacter bacteraemia. Eur J Intern Med. 2009; 20 (5): 540-544. 10.1016/j.ejim.2009.05.005.

22. Ballouz T, Aridi J, Afif C, et al. Risk Factors, Clinical Presentation, and Outcome of Acinetobacter baumannii Bacteremia. Front Cell Infect Microbiol. 2017;7:156. doi: 10.3389/ fcimb.2017.00156

23. Guo N, Xue W, Tang D, et al. Risk factors and outcomes of hospitalized patients with blood infections caused by multidrug-resistant Acinetobacter baumannii complex in a hospital of Northern China. Am J Infect Control. 2016;44(4):e37-e39. doi:10.1016/j.ajic.2015.11.019

24. Ballouz T, Aridi J, Afif C, et al. Risk factors, clinical presentation, and outcome of Acinetobacter baumannii bacteremia. Front Cell Infect Microbiol. 2017;7:1-8.

25. Falagas ME, Bliziotis IA, Siempos II. Attributable mortality of Acinetobacter baumannii infections in critically ill patients: asystematic review of matched cohort and case-control studies. Crit Care. 2006; 10(2): R48

26. Du X, Xu X, Yao J, et al. Predictors of mortality in patients infected with carbapenem-resistant Acinetobacter baumannii: A systematic review and meta-analysis. Am J Infect Control. 2019;47(9):1140-1145. doi:10.1016/j.ajic.2019.03.003

27. Kim YJ, Kim SI, Hong KW, et al. Risk factors for mortality in patients with carbapenem-resistant Acinetobacter baumannii bacteremia: impact of appropriate antimicrobial therapy. J Korean Med Sci. 2012;27(5):471-475.

28. Joung $M K$, Kwon KT, Kang CI, et al. Impact of inappropriate antimicrobial therapy on outcome in patients with hospital-acquired pneumonia caused by Acinetobacter baumannii. J Infect. 2010;61(3):212-218. doi:10.1016/j.jinf.2010.06.014

29. Inchai J, Pothirat C, Liwsrisakun C, et al. Ventilator-associated pneumonia: epidemiology and prognostic indicators of 30-day mortality. Jpn J Infect Dis. 2015;68(3):181-186. doi:10.7883/yoken.JJID.2014.282

30. Leão ACQ, Menezes PR, Oliveira MS, et al. Acinetobacter spp. are associated with a higher mortality in intensive care patients with bacteremia: a survival analysis. BMC Infect Dis 2016;16:386-370.

31. https://www.euro.who.int/en/health-topics/disease-prevention/antimicrobial-resistance/ publications/2020/central-asian-and-european-surveillance-of-antimicrobial-resistance.-annual-report-2020 (Erișim tarihi: 13 Aralk 2020) 